\title{
내장비만
}

\section{Visceral Obesity}

\author{
유 형 준 | 한림의대 내과 | Hyung Joon Yoo, MD \\ Department of Internal Medicine, Hallym University College of Medicine \\ E-mail :yooyoo1@kornet.net
}

J Korean Med Assoc 2007; 50(8): 725 - 728

\section{Abstract}

\begin{abstract}
$\mathrm{M}$ ultiple lines of evidence support the thesis that visceral adiposity is causally related to insulin resistance and the metabolic syndrome. Visceral adipose tissue is biochemically quite distinct from subcutaneous adipose tissue. It has become increasingly evident that the effects of visceral adiposity must be mediated by multiple factors. The release of free fatty acid from visceral adipose tissue in obese individuals has been reported to account for $20 \%$ of that delivered to the liver, and it is unlikely that the contribution of visceral fat to the free fatty acid flux in the circulation is the major mechanism of insulin resistance. Adiponectin and other newly discovered adipokines are likely to contribute to attenuate the effects of visceral obesity onto insulin resistance and metabolic syndrome. Insulin resistance and the metabolic impacts are the consequence of the metabolic effects of the products being released from the adipose tissue rather than an effect of the absolute mass of the fat. Adipose tissue releases free fatty acids and cytokines and modulates the secretion of a large number of metabolically active adipokines. Abdominal circumference is one of indicators for visceral obesity. The abdominal circumference values among Koreans are discussed by active groups.
\end{abstract}

Keywords : Visceral obesity; Insulin resistance; Adipokines; Free fatty acids; Oxidative stress; Waist circumference

핵 심 용 어 : 내장비만; 인슐린 저항성; 아디포카인; 유리지방산; 산화스트레스; 허리둘레

\section{내장비만의 병태-내장비만과 인슐린 저항성}

나 장지방은 중성지방을 축적하기 쉽고 연소되기 쉬운 조직이며 따라서 내장지방이 축적되었을 때에 공복 시에 중성지방의 분해산물인 유리지방산과 글리세롤이 과 다하게 방출된다고 생각해왔다. 내장지방은 문맥과 이어져 있기 때문에 방출된 유리지방산과 글리세롤은 직접 간으로 유입되어 이상지질혈증, 고혈당, 나아가서는 인슐린 이화장
애를 일으켜 인슐린 저항성으로 발전한다는 것이다. 아디포사이토카인 관여 개념 이외에도 지방조직 이외의 말초장기에서도 다양한 내분비인자가 생성되어 생체 항상 성 유지와 관련되며 이들의 생성 이상이 다양한 질환으로 발전된다는 사실이 밝혀지고 있다. 축적된 내장지방으로부 터 보다 많이 생성되고 내장지방 축적상태에서 혈중농도가 상승하는 분비인자(비스파틴, visfatin)에 대한 연구 결과가 발표되었다. 이 인자가 인슐린 같은 에너지 축적효과를 가지 
므로 전신의 장기를 에너지 과잉상태로 만들어 내장지방 축 적시 여러 가지의 질환으로 이어지게 할 가능성을 띠고 있 다. 아울러 골격근유래인자 musclin, 간유래인자 Angpt13, 위세포유래인자 그레린 같은 새로운 인자의 발견과 더불어 소장유래인자 뿐만 아니라 점점 의학적 중요성이 높아지고 있는 레닌-안지오텐신-알도스테론계의 역할도 주목받고 있다 $(1,2)$.

\section{내장비만과 인슐린 저항성의 연관성을 설명하는 기전}

복부 비만(내장지방 비만)과 인슐린 저항성의 인과관계 를 규명할 수 있는 뚜렷한 근거는 없지만 둘 사이의 연관성 을 설명할 수 있는 가설은 몇 가지가 있다.

첫 번째 연결고리는 유리지방산이다(Figure 1).

축적된 내장지방에서 유리된 과다한 지방산이 간문맥을 통해 간으로 유입되면 간내 당생성이 증가하고 VLDL-TG 분비가 증가하면서 당불내성, 고중성지방혈증이 잘 생긴다. 지방산이 간내 인슐린 제거를 억제하는 작용으로 인해 고인 슐린혈증도 유발된다. 혈중 유리지방산 농도는 전체 지방량 의 영향을 받지만 지방분해 속도는 부위마다 다르다. 내장 지방은 복부나 하체의 피하지방보다 지방분해 속도가 더 빠 르고 내장지방의 지방분해는 카테콜라민의 자극에 더 민감 하며 인슐린에 의한 억제 작용은 상대적으로 덜 받는다. 결 국 내장지방의 지방분해가 더 빨리, 더 잘 일어나는 기전은 지방분해를 자극하는 $\alpha$-아드레날린수용체(adrenoceptor) 에 대한 민감도는 더 높은 반면, 지방분해를 억제하는 $\alpha 2-$ 아드레날린수용체 및 아데노신, 인슐린의 수용체에 대한 민 감도는 더 낮기 때문이다. 한편, 혈중 유리지방산 농도가 증 가하면 근육에서의 지방산 이용률이 증가하면서 근육내 중 성지방 농도가 올라간다. 이는 근육의 인슐린을 통한 포도 당 흡수를 감소시킨다. 근육내 지방산 대사 속도가 증가하 면 포도당-지방산 회로(Randle cycle)가 활성화되면서 인 슐린에 의한 글리코겐 합성을 저해한다. 혈중 유리지방산 농도가 올라가면 췌장 $\beta$-세포의 인슐린 분비 기능에 직접 영향을 끼쳐 당불내성을 일으킬 수도 있다.

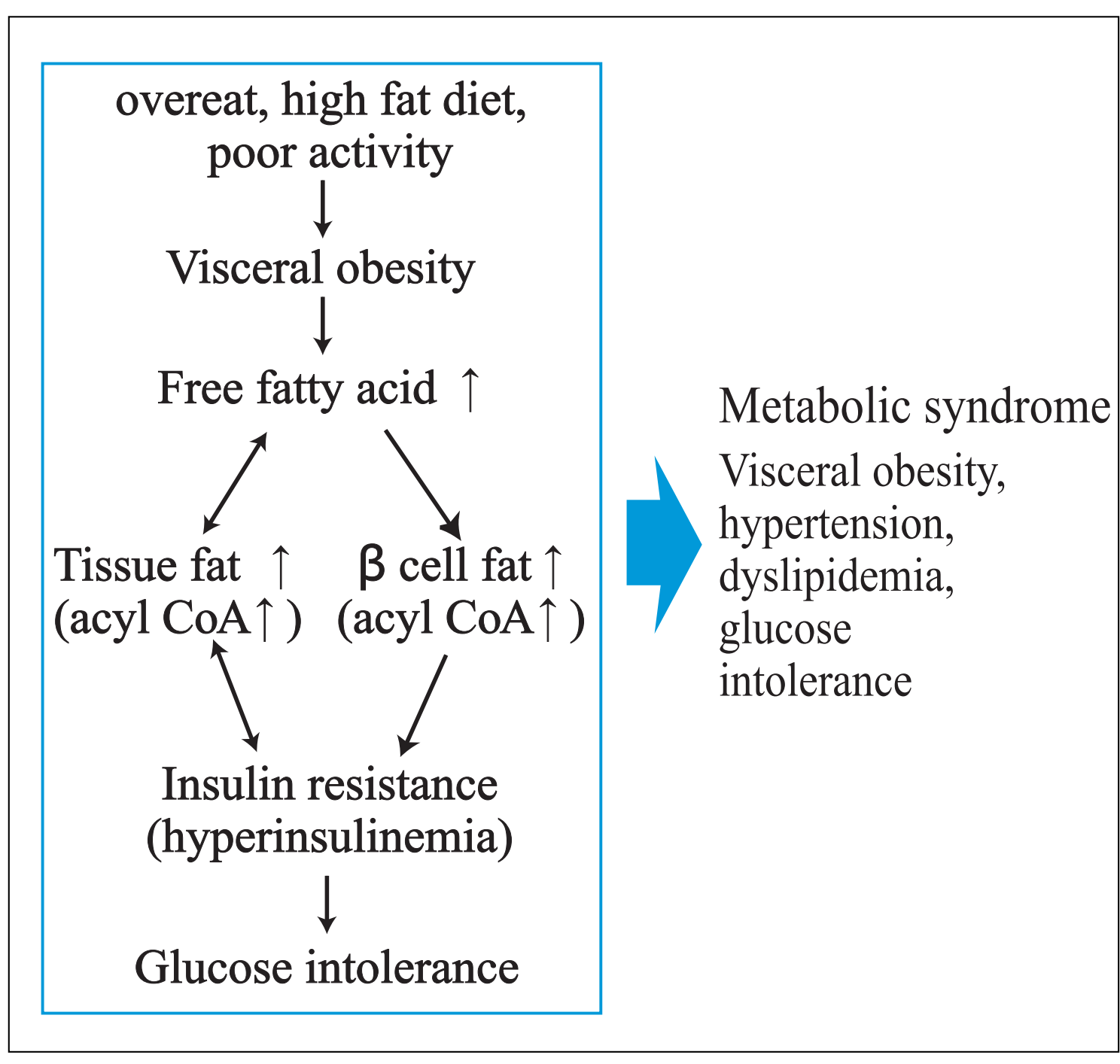

Figure 1. Lipotoxicity hypothesis in metabolic syndrome.

두 번째는 내장지방 조직에서 분비되는 렙틴, PAI-1 (plasminogen activator inhibitor-1), TNF- $\alpha$, Interleukin (IL)-6 등이 일련의 과정을 거쳐 인슐린 저항성을 유발한다 는 것이다.

또 하나의 메카니즘으로서 지방세포에서 분비되는 adipocytokine, 특히 혈전형성 촉진인자인 PAI-1 (plasminogen activator inhibitor type 1)의 생산촉진 및 아디포 넥틴의 생산저하에 의해 혈전증과 인슐린 저항성, 당대사이 상, 고혈압 나아가 동맥경화로 이어진다고 여겨지고 있다 (3 5).

렙틴은 내장지방 조직보다 피하지방 조직에서 더 많이 생 성되고 분비된다. 따라서 지방이 피하 부위보다 복강내 부 위에 더 축적이 되어도 내장지방에서의 렙틴 분비가 상대적 으로 적기 때문에 지방량이 증가하는 데 따른 렙틴의 반응 이 적절하게 이루어지지 못할 수 있으며 따라서 내장지방 축적과 이에 따른 인슐린 저항성이 증가할 수 있다는 것이 다. 반면 PAI-1은 내장지방에서 더 많이 분비된다. 혈중 PAI-1 농도가 증가함에 따라 인슐린 저항성도 증가하며, 이 는 인슐린 저항성과 관련된 섬유소용해 장애에 관여한다. IL-6는 피하지방보다 내장지방에서 더 많이 분비되는 반 면, $\mathrm{TNF}-\alpha$ 는 차이가 없다. 인슐린 클램프법으로 측정한 말 


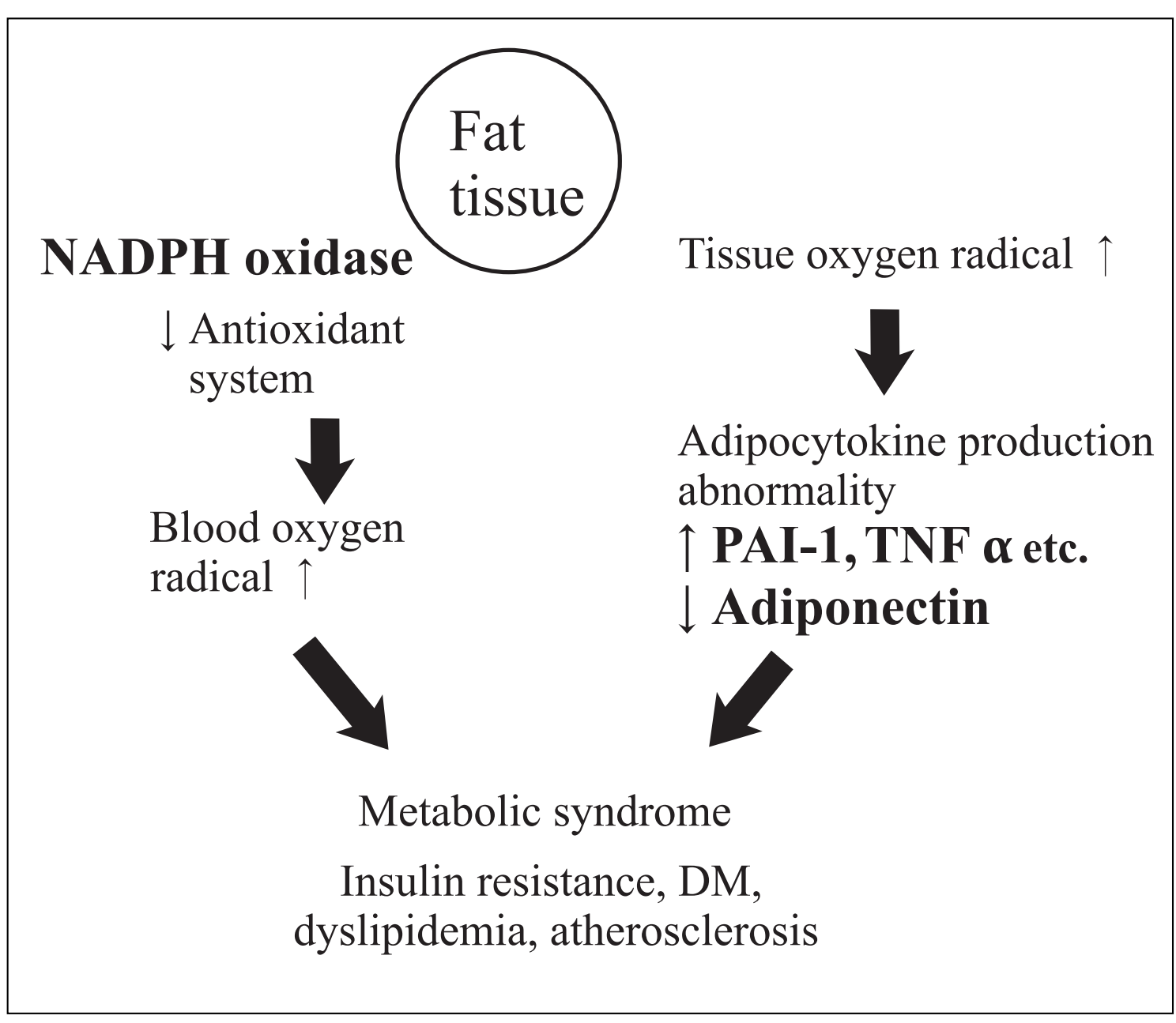

Figure 2. Oxidative stress of fat tissues and metabolic syndrome.

초 조직의 인슐린 저항성은 $\mathrm{TNF}-\alpha$ 의 유전자 발현 증가와 밀접한 관련이 있으며 이는 근육 뿐 아니라 지방 조직에서 도 수용체 상향조절을 보인다.

내장지방의 축적이 인슐린 저항성을 일으킨다고 볼 수도 있지만 반대로 인슐린 저항성이 내장지방 축적의 원인일 수 도 있다. 인슐린 저항성은 지방 세포가 지방산을 더 많이 받 아들이게 만든다. 따라서 피하지방 조직이 인슐린 저항성 상태에 놓이면 지방은 내장지방에 축적되려는 경향을 보일 수 있다. 또 비만 지방조직의 산화스트레스 생성도 대사증 후군과 관계가 있다는 사실이 알려졌다(Figure 2). 즉 비만 지방조직에서는 NADPH 옥시다제 경로의 활성화, 항산화 시스템 저하에 따른 산성 스트레스 생성이 늘어나 adipocytokine의 생성 이상을 초래하며 혈중 산화스트레스 농도 의 상승에 따른 각종 장기기능 이상을 불러 일으켜 성인병 으로 연결된다는 것이다.

최근에는 비만 지방조직에 다량의 탐식세포가 있다는 사 실이 병리학적으로 밝혀져 탐식세포로 인한 다양한 염증성 사이토카인 생성이 병태와 관련이 있을 것으로 보인다. 한 편 활성화 탐식세포는 산화스트레스를 활발히 생성한다는 사실도 알려지면서 비만 지방조직의 산화스트레스 생성증 가는 비대 지방세포와 함께 존재하는 탐식세포 때문이라고 생각된다. 또 다른 설명으로는 내장지방 축적과 인슐린 저
항성이 어떤 다른 생화학적 대사과정에 함께 관련이 있을 가능성이다. 예를 들면 스트레스와 내장지방 비만과의 관련 성이다. 스트레스로 시상하부-뇌하수체 축이 자극을 받으 면 내장지방 비만과 인슐린 저항성이 함께 나타날 수 있다. 또 최근에는 축적된 내장지방세포 내에서 활성형 글루코코 르티코이드 생성이 증가하여 내장지방의 adipocytokine 생성에 이상이 생기고 혈중 활성형 글루코코르티코이드 농 도가 상승하여 쿠싱증후군 같은 당 - 지방질대사이상으로 발전한다고 보기도 한다.

\section{내장비만의 측정}

가장 정확하다고 알려진 것은 CT를 이용한 내장지방 면 적 또는 부피를 재는 것이다. 그러나 내장 지방의 양 또는 크 기와 대사 변화 정도가 비례하는 것만은 아니라는 연구 결 과들이 적지 않다(9). 따라서 정확한 지방의 양을 재는 것이 내장지방의 대사영향을 반드시 가장 잘 반영할 것이라는 기 대는 곤란하다. 이러한 사실과 함께 경제적 고려를 더하여 일반적으로 허리둘레로 측정하여 복부비만을 파악함으로써 내장지방의 정도를 가능하고 있는 것이 현실이다. 실제로 허리둘레는 현재 가장 널리 이용되고 있는 내장지방의 척도 임에 분명하다.

2005년 IDF (International Diabetes Federation)는 복 부비만을 대사증후군 진단의 필수 항목으로 결정하였으며 복부비만을 평가하는 허리둘레 분별점에 대해서 민족적 특 성을 고려한 기준을 사용할 것을 제안하는 등 비만 및 복부 비만의 기준에 대해 최근 각 민족 고유의 기준을 설정하여 적용하는 것이 타당하다고 여겨지고 있다. 이에 한국인에 적합한 복부비만의 기준을 설정할 필요성은 현저하고 관련 단체들의 실질적 노력이 이루어 지고 있는 실정이다.

예를 들어 대한비만학회는 '한국인에서 복부비만의 기준 을 위한 허리둘레 분별점은 남자에서 $90 \mathrm{~cm}$, 여자에서 $85 \mathrm{~cm}$ 로 정하며 남자에서 $90 \mathrm{~cm}$ 이상, 여자에서 $85 \mathrm{~cm}$ 이상 일 때 복부비만으로 정의하며, 이러한 기준은 한국인에서 새로운 자료가 구축되는 대로 언제든지 개정 가능하다' 는 연구보고에 근거한 제안을 한 바 있다. 


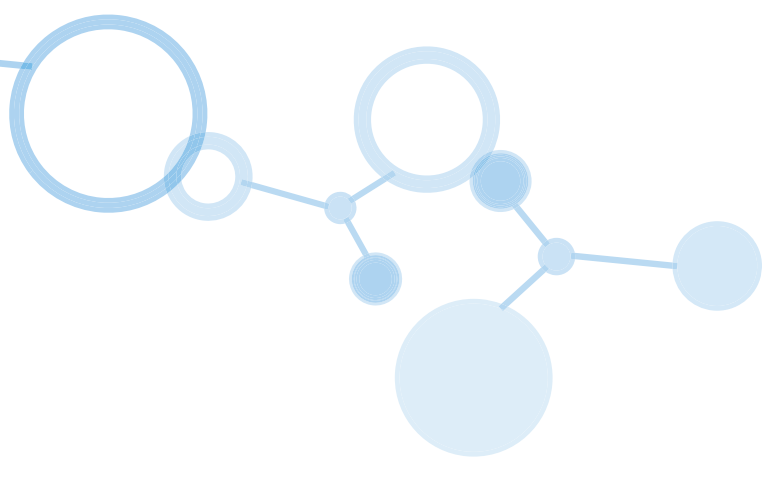

내장지방의 개선

식사, 운동, 행동수정 등의 생활양식 변화와 약물 또는 수 술적 치료가 내장지방의 감소를 유도한다는 것은 주지의 사 실이다. 긴 사설이 없이도 이러한 내장지방의 감소가 인슐 린저항성, 대사증후군에 이로운 효과를 더할 것이라는 점은 쉽게 이해된다.

\section{참고문헌}

1. Korean Society for the Study of Obesity: Metabolic syndromepathological molecular biolocy, ed. by Matsuzawa, et al. (Korean version). Seoul: Euihakmunhwasa, 2005.

2. Kim JY, Shin HW, Jeong IK, Yoo HJ, et al. Correlation among adiponectin, leptin, ghrelin, insulin resistance and cardiovascular risk factors according to the degree of obesity. Korean $\mathrm{J}$ of Internal Medicine 2005; 69: 631-641.

3. Matsuzawa Y. Pathophysiology and molecular mechanisms of visceral fat syndrome. Diabetes Metab Rev 1997; 13: 3-13.

4. Raven GM. Role of insulin resistance in human disease. Diabetes 1988; 37: 1595-1607.

5. Grundy SM. Hypertriglyceridemia, insulin resistance, and the metabolic syndrome. Am J Cardiol 1999; 83: 25-29.

6. Miyazaki Y, Mahankali A, Matsuda M, Mahankali S, Hardies J, Cusi K, Mandarino LJ, DeFronzo RA. Effect of pioglitazone on abdominal fat distribution and insulin sensitivity in type 2 diabetic patients. J Clin Endocrinol Metab 2002; 87: 2784 2791

7. Lee SY, Park HS, Kim DJ, Han JH, Kim MS, Cho GJ, Kim DY, Kwon HS, Kim SR, Lee CB, Oh SJ, Park CY, Yoo HJ. Appro priate waist circumference cutoff points for central obesity as main component of the new International Diabetes Federation definition in Korean adults. Diabetes Research and Clinical Practice (accepted, 24 April 2006).

8. Park HS, Park CY, Oh SW, Yoo HJ. Prevalence of Obesity and Metabolic Syndrome in Korean Adults. Obesity Reviews 2007 (in press).

9. Korean Society for the Study of Obesity. Metabolic syndrome practical guide. Seoul: Euihakmunhwasa, 2005.

\section{Peer Reviewer Commentary}

\section{박 철 영 (성균관의대 내분비내과)}

2000년대 의학계의 몇 가지 주목받는 것 중 하나는 지방세포의 재조명에 대한 것이다. 이전에 에너지의 저장 창고 역 할에 머물렀던 지방세포가 많은 호르몬, 펩티드 등을 분비하면서 에너지 대사를 직접 조절하고 있은 가장 활동적인 내 분비-대사 기관 중의 하나라는 것이다. 이 중에서 지방도 다 같은 지방이 아니라 피하지방보다는 내장지방이 당뇨병을 비롯한 여러 대사 질환의 중요한 위험인자라는 것이다. 본 논문은 이런 관점에서 내장지방이 질환을 일으키는 기전에 대해 비교적 알기 쉽게 조명하였다. 또한 임상적인 견지에서 내장지방 측정 방법 및 기준에 대해서도 제시를 하였다. 그 러므로 건강상의 체중 조절이라는 관점은 피하지방이 아닌 내장지방의 감소에 중점을 두어야 한다. 최근 논문들은 지방 흡입에 의한 피하지방의 감소, 몇몇 약물에 의한 체중 감소보다는 식사 및 운동요법 등에 의한 내장지방의 감소가 우리 가 원하는 건강상의 대사지표들을 개선시키는 데 더욱 뚜렷한 결과를 보이고 있다는 것을 명심하여야 한다. 